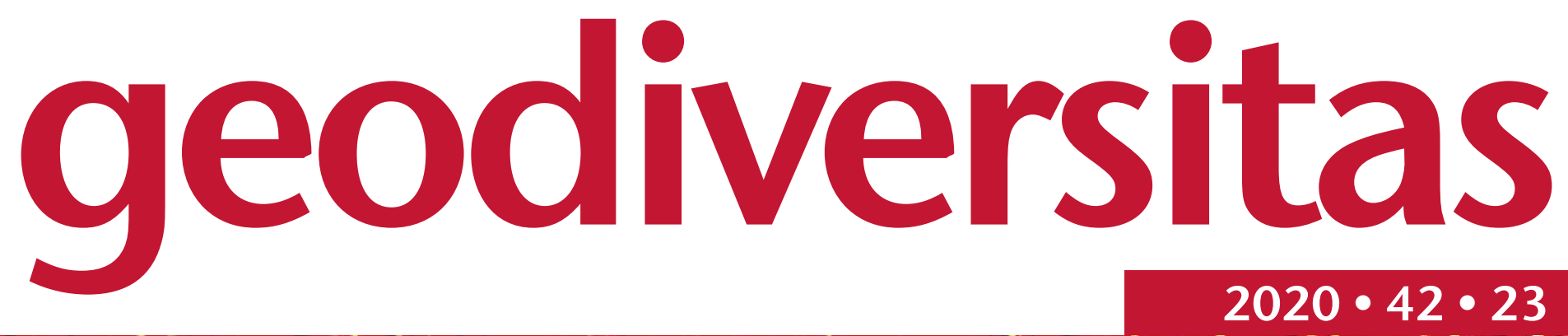

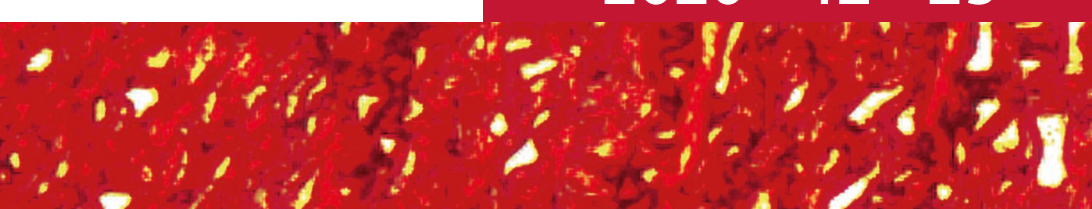
6. The first report of Lesbosoxylon suiss \& yelitzelos - from the eafly-míd dle Miocene of eastern,Anáfolitaly i.

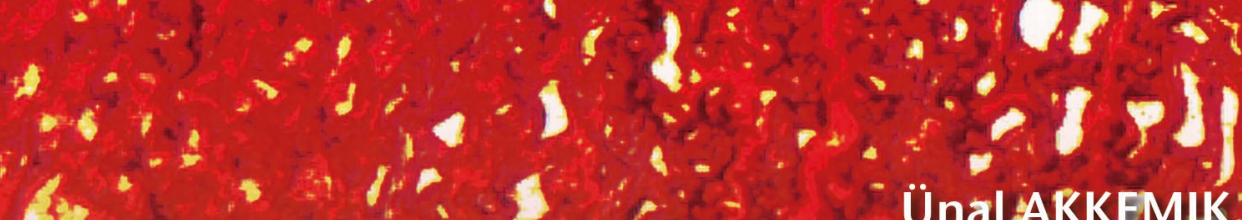
Ünal ARKEMIK;

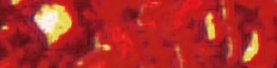

tis

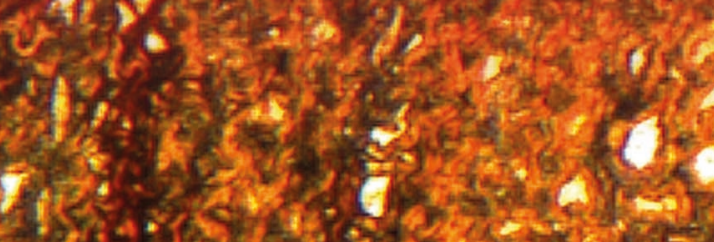
W.

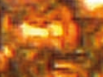

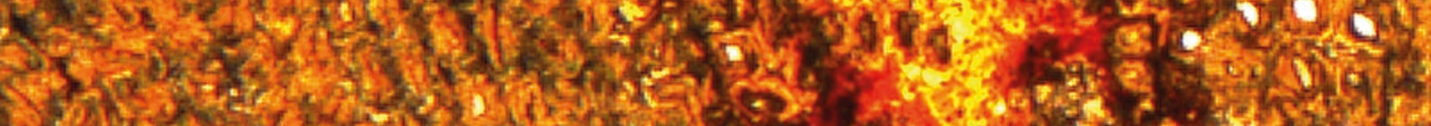

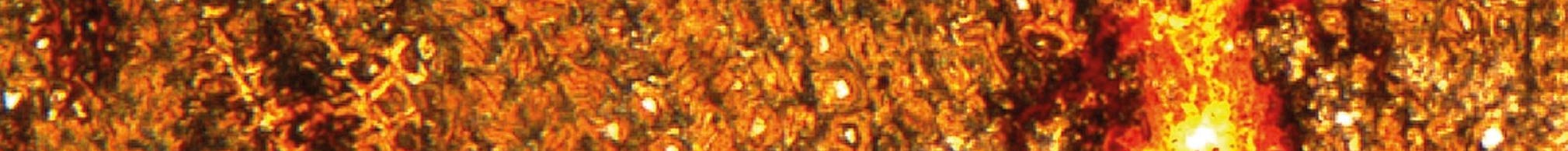

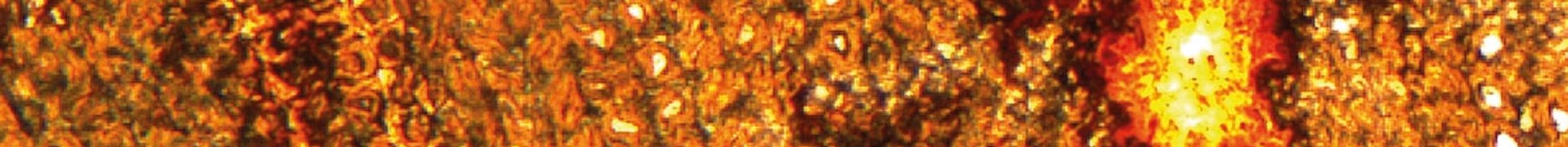

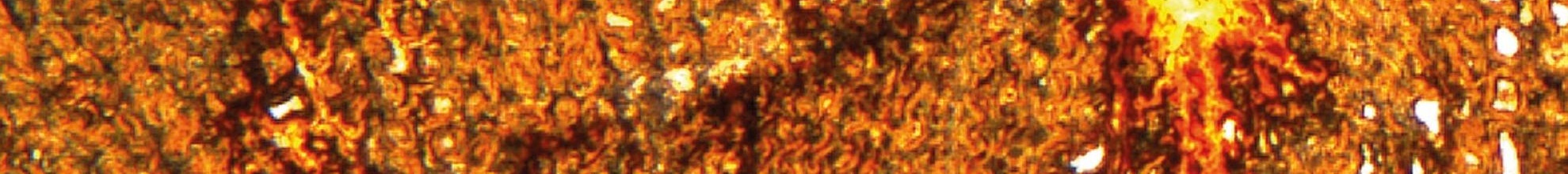


DiReCteur de LA PUblication / PUBLICATION DIRECTOR : Bruno David,

Président du Muséum national d'Histoire naturelle

RÉDACTEUR EN CHEF / EDITOR-IN-CHIEF: Didier Merle

ASSISTANT DE RÉDACTION / ASSISTANT EDITOR: Emmanuel Côtez (geodiv@mnhn.fr)

Mise EN PAGE / PAGE LAYOUT: Emmanuel Côtez

COMITÉ SCIENTIFIQUE / SCIENTIFIC BOARD:

Christine Argot (Muséum national d'Histoire naturelle, Paris)

Beatrix Azanza (Museo Nacional de Ciencias Naturales, Madrid)

Raymond L. Bernor (Howard University, Washington DC)

Alain Blieck (chercheur CNRS retraité, Haubourdin)

Henning Blom (Uppsala University)

Jean Broutin (Sorbonne Université, Paris, retraité)

Gaël Clément (Muséum national d'Histoire naturelle, Paris)

Ted Daeschler (Academy of Natural Sciences, Philadelphie)

Bruno David (Muséum national d'Histoire naturelle, Paris)

Gregory D. Edgecombe (The Natural History Museum, Londres)

Ursula Göhlich (Natural History Museum Vienna)

Jin Meng (American Museum of Natural History, New York)

Brigitte Meyer-Berthaud (CIRAD, Montpellier)

Zhu Min (Chinese Academy of Sciences, Pékin)

Isabelle Rouget (Muséum national d'Histoire naturelle, Paris)

Sevket Sen (Muséum national d'Histoire naturelle, Paris, retraité)

Stanislav Štamberg (Museum of Eastern Bohemia, Hradec Králové)

Paul Taylor (The Natural History Museum, Londres, retraité)

COUVERTURE / COVER:

Réalisée à partir des Figures de l'article/Made from the Figures of the article.

Geodiversitas est indexé dans / Geodiversitas is indexed in:

- Science Citation Index Expanded (SciSearch ${ }^{\circledR}$ )

- ISI Alerting Services ${ }^{\circledR}$

- Current Contents ${ }^{\circledR}$ / Physical, Chemical, and Earth Sciences ${ }^{\circledR}$

- Scopus ${ }^{\circledR}$

Geodiversitas est distribué en version électronique par / Geodiversitas is distributed electronically by:

- BioOne ${ }^{\circledR}$ (http://www.bioone.org)

Les articles ainsi que les nouveautés nomenclaturales publiés dans Geodiversitas sont référencés par / Articles and nomenclatural novelties published in Geodiversitas are referenced by:

- ZooBank ${ }^{\circledR}$ (http://zoobank.org)

Geodiversitas est une revue en flux continu publiée par les Publications scientifiques du Muséum, Paris Geodiversitas is a fast track journal published by the Museum Science Press, Paris

Les Publications scientifiques du Muséum publient aussi / The Museum Science Press also publish: Adansonia, Zoosystema, Anthropozoologica, European Journal of Taxonomy, Naturae, Cryptogamie sous-sections Algologie, Bryologie, Mycologie, Comptes Rendus Palevol

Diffusion - Publications scientifiques Muséum national d'Histoire naturelle

CP $41-57$ rue Cuvier F-75231 Paris cedex 05 (France)

Tél. : 33 (0)1 40794805 / Fax: 33 (0)14079 3840

diff.pub@mnhn.fr / http://sciencepress.mnhn.fr

(C) Publications scientifiques du Muséum national d'Histoire naturelle, Paris, 2020

ISSN (imprimé / print): 1280-9659/ ISSN (électronique / electronic): 1638-9395 


\title{
The first report of Lesbosoxylon Süss \& Velitzelos from the early-middle Miocene of eastern Anatolia
}

\author{
Ünal AKKEMIK \\ Istanbul University-Cerrahpaşa, Forestry Faculty, \\ Department of Forest Botany, 34473 Bahçeköy-Sarıer, İstanbul (Turkey) \\ uakkemik@istanbul.edu.tr (corresponding author) \\ Dimitra MANTZOUKA \\ Senckenberg Naturhistorische Sammlungen Dresden, \\ Senckenberg Natural History Collections Dresden \\ Königsbrücker Landstraße 159, D-01109 Dresden (Germany) \\ dimitra.mantzouka@senckenberg.de \\ dmantzouka@yahoo.gr \\ Demet KIRAN YILDIRIM \\ İstanbul Technical University, Mining Faculty, \\ Department of Geological Engineering, Maslak-İstanbul (Turkey) \\ kirand@itu.edu.tr
}

Submitted on 11 July 2019 | accepted on 1 October 2019 | published on 1 October 2020

urn:Isid:zoobank.org:pub:54A81360-9A19-456B-AF72-E4868A4835BA

Akkemik Ü., Mantzouka D. \& Kıran Yıldırım D. 2020. - The first report of Lesbosoxylon Süss \& Velitzelos from the earlymiddle Miocene of eastern Anatolia. Geodiversitas 42 (23): 427-441. https://doi.org/10.5252/geodiversitas2020v42a23. http://geodiversitas.com/42/23

\section{ABSTRACT}

A new fossil pine species from eastern Turkey is described and its botanical affinities are discussed. The sample was collected from the city of Kemaliye, Erzincan province, Turkey, and derives from the early-middle Miocene Divriği formation. Transverse, tangential and radial sections were taken from the petrified wood, and its palaeoxylotomical features were investigated. Based on its anatomical features including idioblastic cells in rays a new fossil-species of the genus Lesbosoxylon Süss \& Velitzelos was identified as Lesbosoxylon kemaliyensis Akkemik \& Mantzouka, sp. nov. Diagnostic features of the new species are: Transition from earlywood to latewood mostly gradual; axial and radial resin canals with thin-walled epithelial cells present; latewood tracheids thin to thick walled; bordered pits on radial

KEY WORDS

Pinaceae,

Miocene,

Sivas Basin,

wood anatomy,

conifer,

biogeography,

new species. walls of tracheids 1-2(-3) seriate; crassulae common; rays heterocellular, uniseriate, partly biseriate; uniseriate rays up to 27 cells high; fusiform rays up to 30 cells high; axial parenchyma occasionally present; ray tracheids 2-3 rows; cell walls of ray tracheids smooth; cross-field pitting pinoid, 1-2(-6) pits per cross-field. Detailed investigation of the botanical affinities of the new fossil wood suggested that the most closely related modern species is Pinus canariensis $\mathrm{C}$. Sm in Buch, a relict species from the Canary Islands. 


\begin{abstract}
RÉSUMÉ
Le premier rapport d'une espèce de Lesbosoxylon Süss \& Velitzelos du Miocène inférieur-moyen de l'Anatolie orientale.

Une nouvelle espèce de pin fossile de l'est de la Turquie est décrite et ses affinités botaniques sont discutées. L'échantillon, a été collecté dans la ville de Kemaliye (province d'Erzincan, en Turquie), et provient de la formation Divriği du Miocène inférieur à moyen. Des sections transversales, tangentielles et radiales ont été prélevées du bois pétrifié et ses caractéristiques paléoxylotomical ont été observées. Basé sur ses caractéristiques anatomiques, notamment des cellules idioblastiques dans les rayons, une nouvelle espèce fossile du genre Lesbosoxylon Süss \& Velitzelos a été identifiée comme étant Lesbosoxylon kemaliyensis Akkemik \& Mantzouka, sp. nov. Les caractéristiques diagnostiques de la nouvelle espèce sont les suivantes: transition du bois d'origine au bois final est essentiellement progressive; canaux de résine axiaux et radiaux avec présence de cellules épithéliales à parois minces; trachéides de bois final sont à parois mince à épaisses; fosses bordées sur les parois radiales des trachéides

MOTS CLÉS

Pinaceae,

Miocène,

bassin de Sivas, anatomie du bois, conifere,

biogéographie, espèce nouvelle. 1-2(-3), sériate, crassulae commun, rayons hétérocellulaires, unisériés, partiellement bisérisés; rayons unisériés jusqu’à 27 cellules de haut; rayons fusiformes jusqu'à 30 cellules de haut; parenchyme axial occasionnellement présent; trachéides à rayons de 2-3 rangées; les parois cellulaires des trachéides à rayons sont lisses; ponctuations par champ de croisement pinoïde, 1-2(-6) ponctuations par champ. Une étude détaillée des affinités botaniques du nouveau bois fossile suggère que les espèces les plus modernes est étroitement liée à Pinus canariensis C. Sm à Buch, une espèce relictuelle des îles Canaries.
\end{abstract}

\section{INTRODUCTION}

Late Oligocene to Pliocene strata in the Eastern Mediterranean region have yielded a particularly rich plant fossil record. This record includes petrified woods (e.g. Sayadi 1973; Selmeier 1990, 2001; Kayackk et al. 1995; Akkemik et al. 2005, 2009, 2017, 2018; Akkemik \& Sakınç 2013; Bayam et al. 2018; Iamandei et al. 2018; Güngör et al. 2019), macrofossils (e.g. Kasapligil 1977; Denk et al. 2017a, b, c; Güner et al. 2017) and fossil pollen (e.g., Sancay et al. 2006; Yavuz-Işsı 2007; Karlıŏlu et al. 2009; Akkiraz et al. 2011; Bouchal et al. 2016, 2017). Recent studies (Bouchal et al. 2016, 2017; Denk et al. 2017a, b) showed that during the early and early middle Miocene, Turkey was characterized by a forest vegetation dominated by conifers and evergreen and deciduous Fagaceae. Investigations of plant fossil remains (Kayseri Özer et al. 2017; Akkemik et al. 2018) indicate humid to locally dry climates in the late Oligocene to earliest Miocene and warm temperate climates during the early and middle Miocene in Turkey (Akkiraz et al. 2011; Mantzouka et al. 2015; Denk et al. 2017a, b; Bouchal et al. 2016, 2017).

The petrified wood record in the Aegean Basin and Anatolia is remarkably rich and includes many fossil-species from the Neogene such as Sequoioxylon egemenii Özgüven-Ertan (Özgüven-Ertan 1971), Cupressinoxylon akdiki ÖzgüvenErtan (Özgüven-Ertan 1977), Lesbosoxylon paradoxum Süss \& Velitzelos, L. pseudoparadoxum Süss \& Velitzelos (Süss \& Velitzelos 2010), Taxaceoxylon biseriatum Süss \& Velitzelos (Süss \& Velitzelos 1994a), Taxodioxylon megalonissum Süss \& Velitzelos and Glyptostroboxylon microtracheidale Süss \& Velitzelos (Süss \& Velitzelos 1997), Tetraclinoxylon velizelosi Süss (Süss 1997), Thujoxylon antissum Süss \& Velitzelos (Süss \& Velitzelos 1998), Chimairoidoxylon lesboense Süss \& Velitzelos (Süss \& Velitzelos 1999), Podocarpoxylon articula- tum Süss \& Velitzelos and P. graciliradiatum Süss \& Velitzelos (Süss \& Velitzelos 2000), Chimairoidoxylon conspicuum Süss \& Velitzelos (Süss \& Velitzelos 2001), Ginkgoxylon lesboense Süss \& Velitzelos and G. diversicellulatum Süss (Süss 2003), Lesbosoxylon diversiratiatum Süss \& Velitzelos and L. graciliradiatum Süss \& Velitzelos and L. ventricosurradiatum Süss \& Velitzelos (Süss \& Velitzelos 2010), Cryptocaryoxylon lesbium Mantzouka and C. lemnium Mantzouka (Mantzouka 2018), Pinuxylon alonissianum Mantzouka \& Sakala (Mantzouka et al. 2019), Pistacioxylon ufukii Akkemik and Zelkovoxylon yesimae Akkemik (Akkemik et al. 2018), Laurinoxylon thomasii Akkemik, Mimosoxylon ceratonioides Akkemik, Pterocaryoxylon tuncayi Akkemik, Prunoidoxylon aytugii Akkemik (Akkemik et al. 2019), Cupressinoxylon pliocenica Akkemik and Cercioxylon zeynepae Akkemik (Akkemik 2019).

Among these petrified wood taxa, pine was found to be one of the most common woods and various species of pine woods were identified. Within pine wood, two major types corresponding to two subgenera can be referred to as haploxylon and diploxylon types (Mantzouka et al. 2019). Furthermore, another diagnostic feature was the presence of axial parenchyma. Together, these features provide reliable information for assessing botanical affinities of fossil wood remains (Wang et al. 2017; Mantzouka et al. 2019). The aim of the present study is to describe a new fossil pine species from east-central Turkey and to discuss its botanical and biogeographic affinities.

\section{GEOLOGICAL SETTING}

The study area is located in the southeast of Divriği, Sivas province, east-central Turkey (Fig. 1). Since the Late Cre- 


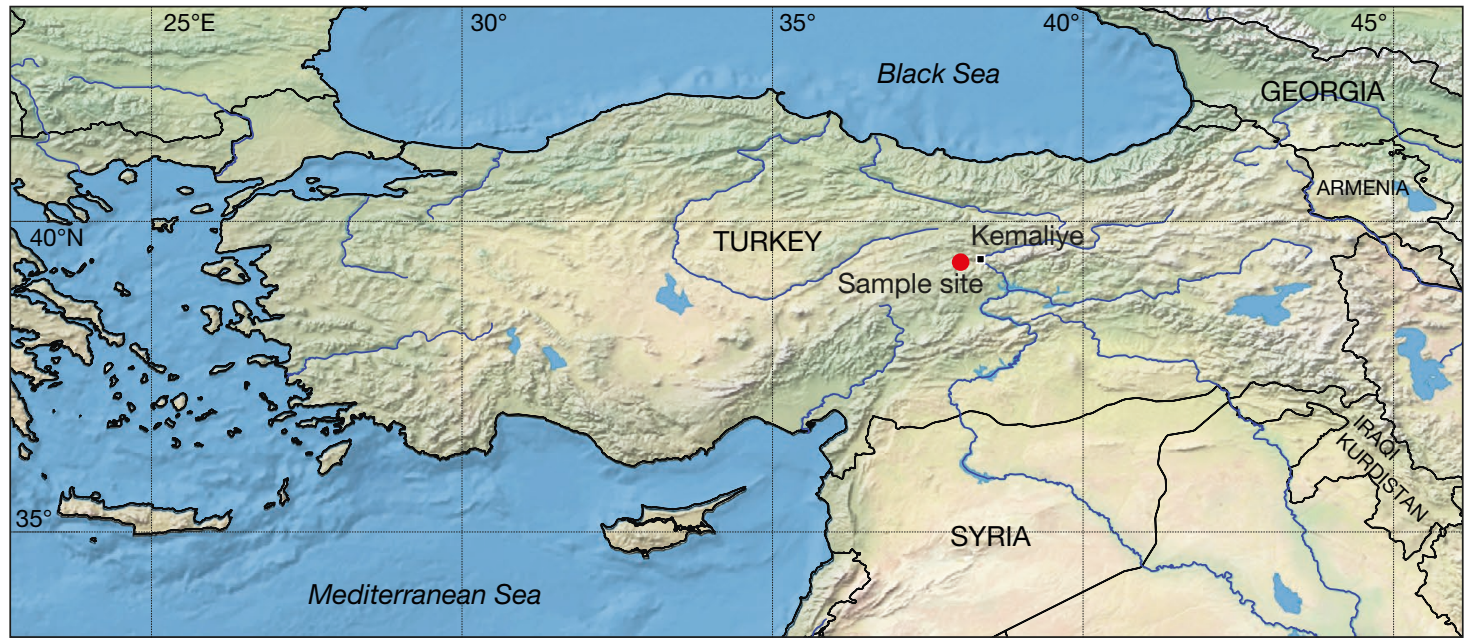

FIG. 1. - The location of the site, in the Erzincan province, east-central Turkey.

taceous, the Middle East region, Eurasia and Africa-Arabia were involved in the formation of the Alpine belt resulting from plate convergence (Poisson et al. 1995). The corresponding N-S shortening caused the closure of the NorthNeotethys ocean basins and finally the collision between the Eurasian plate, the Antolian block and the Arabian plate (Poisson et al. 1995).

The convergence of Arabian and Eurasian plates since the mid-Miocene has resulted in the Tibetan-type crustal thickening of the Anatolian Block with the development of the right lateral strike-slip North Anatolian Fault Zone (Şengör \& Kidd 1979) and the left lateral strike-slip East Anatolian Fault Zone (Dewey et al. 1986). Between these two major faults, the Anatolian Block continues to move westward to accommodate the constant convergence between the Arabian and Eurasian plates (Şengör \& Yılmaz 1981; Cater et al. 1991).

The formation of sedimentary basins on the Tauride - Anatolide Platform was due to the N-S convergence between the Pontides and Tauride - Anatolide Platform since the Late Cretaceous period after the closure of the northern branch of the Neotethys ocean along the İzmir-Ankara-Erzincan suture region (Gürer \& Aldanmaz 2002).

A series of sedimentary basins were created on the TaurideAnatolide Platform during the Late Cretaceous-Cenozoic period in different areas (Şengör \& Yılmaz 1981; Görür et al. 1984; Cater et al. 1991; Gürer 1996; Poisson et al. 1996; Erdogan et al. 1996).

The Sivas Basin evolved from marine to lacustrine and fluvial sedimentary environments (Tekin 2001) and is one of the largest Central Anatolian basins which developed during the closure of the northern branch of the Neotethys ocean (Gökten 1993; Poisson et al. 1995) between the Pontide Orogen to the north and the Tauride Orogen to the south (Kelling et al. 1989; Cater et al. 1991). In addition, the Sivas Basin is considered as one of the most important sedimentary basins, in terms of its hydrocarbon potential, in the Central Anatolian region of Turkey (Kavak et al. 1997).
Ophiolitic melange, volcano-sedimentary unit, granitoid rocks and Cenozoic sediments characterize the Sivas-Divriği region including the study area (Yilmaz et al. 2001). The Cenozoic system is represented by different units to the north and south of the study area, including the early Eocene Subaşı formation, composed of clastic and volcanic rocks and the middle-late Eocene Bozbel formation which includes clastics and limestones (Bilgiç 2008). The latter formation is overlain unconformably by the clastics of the Oligocene Selimiye formation. Early-middle Miocene units are represented by terrestrial clastics of the Karacaören formation in the north and neritic limestones of the Başpınar formation in the south. The Divriği formation which is composed of conglomerates, sandstone and limestone with gypsum intercalations covers these units unconformably. Further, some of these units are unconformably overlain by the late Miocene-Pliocene Yamadağı volcanics and Pliocene Kangal formation and covered by Quaternary deposits (Bilgiç 2008).

The samples studied in the present paper originate from the early-middle Miocene Divriği formation, which is represented by lacustrine limestones and clastics covering large areas south of the Divriği region (Aktimur et al. 1988, 1990) and amount to $250 \mathrm{~m}$ of thickness (Bilgiç 2008) (Fig. 2).

\section{MATERIAL AND METHODS}

The fossil wood sample (Fig. 3) was collected in the vicinity of the city of Kemaliye, Erzincan province (Fig. 1). It is stored in the Department of Forest Botany, Faculty of Forestry, Istanbul University-Cerrahpasa with the code KEM01.

A piece of the fossil wood was used to produce thin sections, which have a thickness of about 30 microns. Transversal, tangential and radial sections were taken and all microscopic descriptions and photographing were performed on these three sections. The IAWA terminology for coniferous woods (Wheeler et al. 2004) was followed. A number of further references (e.g. Mathiesen 1970; Tidwell et al. 


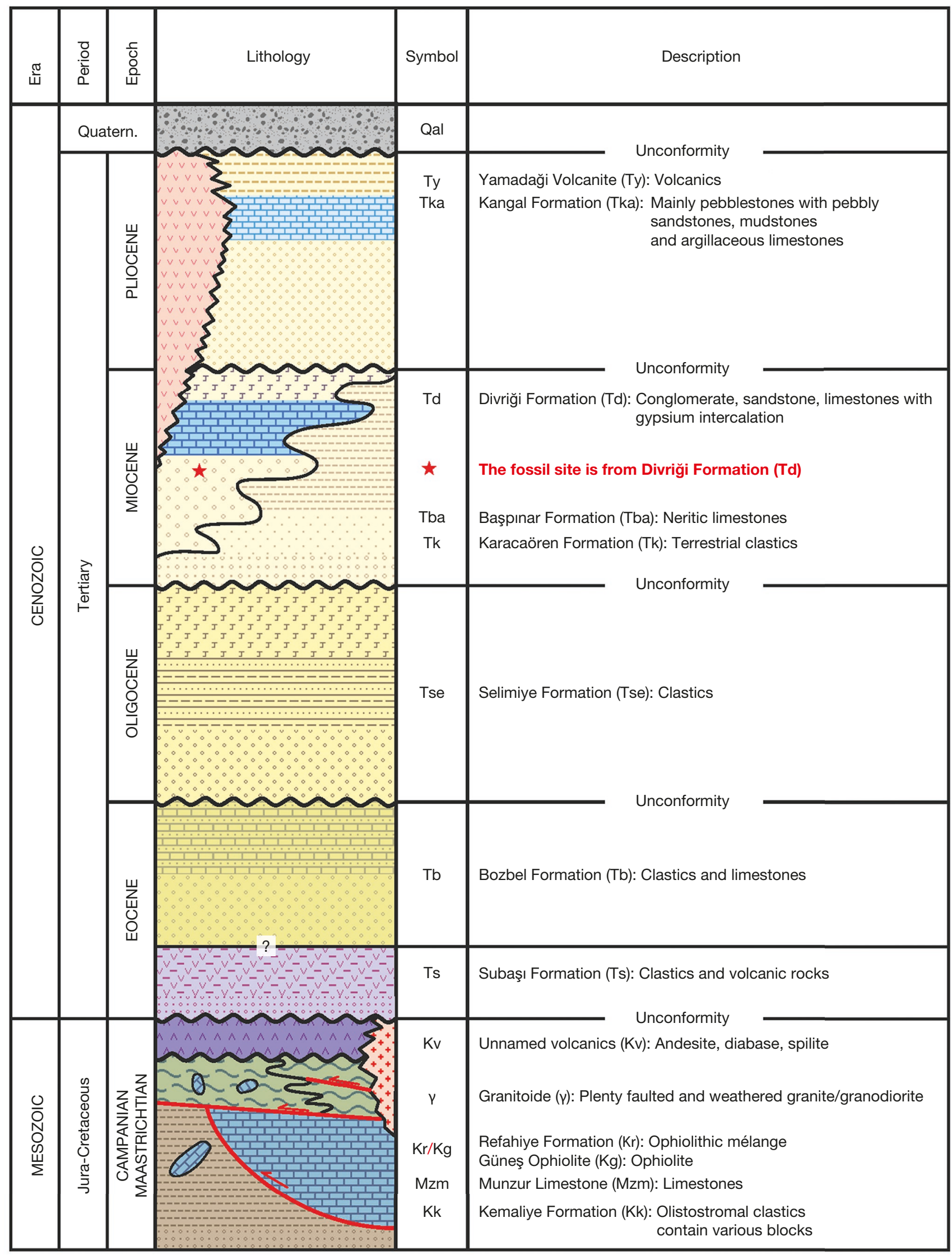

FIG. 2. - Geology and stratigraphic section of the site (early-middle Miocene Divriği formation, Erzincan province, east-central Turkey). 


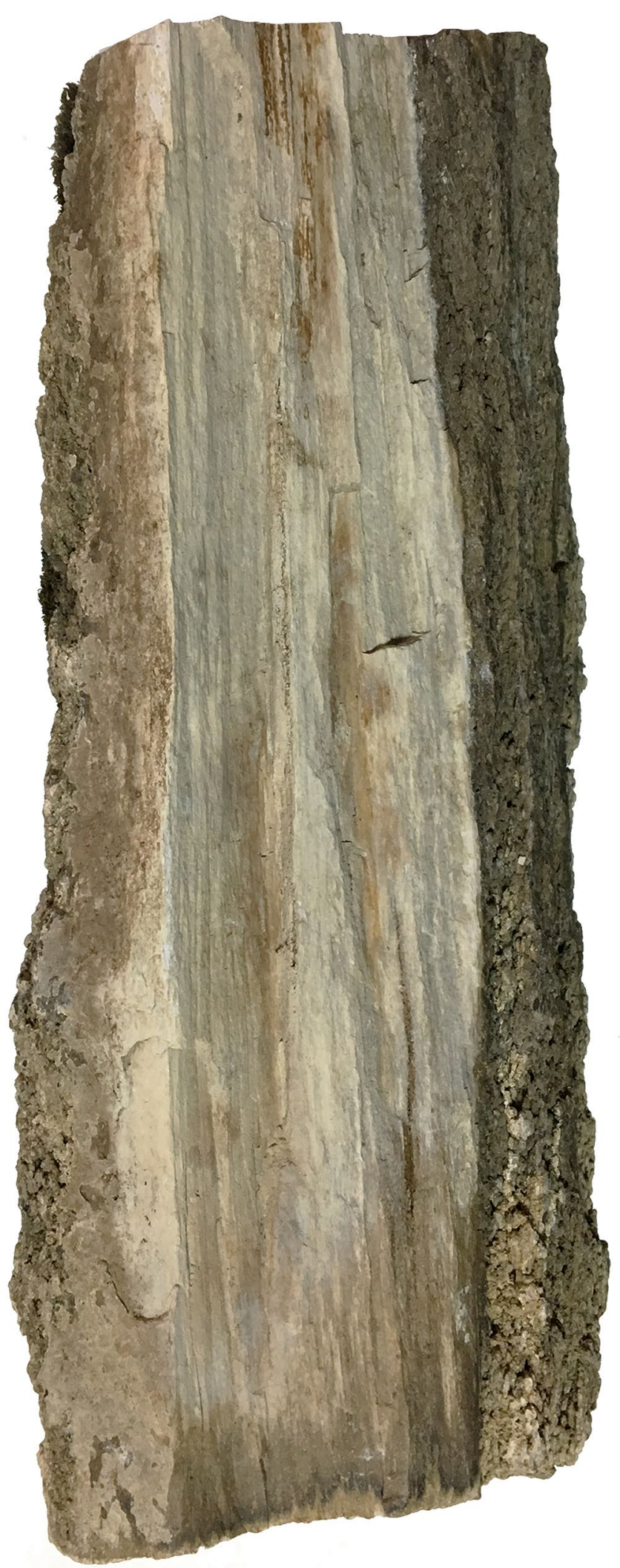

FIG. 3. - The petrified wood used in description (specimen KEM01, $7 \times 8 \times 19 \mathrm{~cm}$, Istanbul University-Cerrahpasa, Faculty of Forestry).

1986; Dolezych \& Schneider 2006; Philippe \& Bamford 2008; Süss \& Velitzelos 1994a, b, 2009, 2010; Akkemik et al. 2016; Blokhina \& Bondarenko 2016; Iamandei et al. 2016a, b; Wang et al. 2017; Bayam et al. 2018; Sakala et al. 2018; Mantzouka et al. 2019; Güngör et al. 2019) were used in the descriptions. 
TABLE 1. - Diameters of tracheids and pits.

\begin{tabular}{lll}
\hline $\begin{array}{l}\text { Diameters of } \\
\text { tracheids and } \\
\text { pits }(\boldsymbol{\mu m})\end{array}$ & In earlywood & In latewood \\
\hline Radial diameter & $53.5(39.8-69.6)$ & $18.6(11.5-29.3)$ \\
$\begin{array}{l}\text { Tangential diameter } \\
\text { Double cell wall }\end{array}$ & $37.2(27.2-47.8)$ & $26.6(17.9-36.1)$ \\
$\quad$ thickness & $14.3(11.5-19.6)$ & $16.5(10.6-23.3)$ \\
$\begin{array}{l}\text { Bordered pits } \\
\text { Cross-field pits }\end{array}$ & $23.5(14.7-31.0)$ & - \\
\hline
\end{tabular}

\section{RESULTS AND DISCUSSION}

The fossil wood belongs to the family Pinaceae and to the fossil-genus Lesbosoxylon Süss \& Velitzelos. The detailed description of the fossil wood is given as follows:

\section{Family PINACEAE L.}

Genus Lesbosoxylon Süss \& Velitzelos

Lesbosoxylon kemaliyensis Akkemik \& Mantzouka, sp. nov. (Figs 3-6)

Plant Fossil Names Registry Number: PFN001780

HOLOTYPE. - Specimen KEM01; repository: Istanbul University-Cerrahpasa, Faculty of Forestry, Department of Forest Botany (designated here).

ETyMology. - The epithet "kemaliyensis" comes from the name of the main city "Kemaliye" nearby the fossil site.

Type HORIZON. - Divriği Formation.

AGE. — Early-middle Miocene.

Type Locality. - Kemaliye (Eğin), Erzincan, Turkey.

DiagnOSIs. - Coniferous wood with resin canals. Growth ring boundaries distinct, transition from earlywood to latewood mostly gradual, axial and radial resin canals with thin-walled epithelial cells, latewood tracheids thin to thick walled, bordered pits on radial walls of tracheids 1-2(-3) seriate, crassulae common, rays heterocellular, uniseriate, partly biseriate, uniseriate rays up to 27 cells high, fusiform rays up to 30 seriate high. Axial parenchyma occasionally present. Ray tracheids 2-3 rows, cell walls of ray tracheids smooth. Cross-field pitting pinoid, 1-2(-6) pits per cross-field, horizontal and end walls of ray parenchyma cells smooth and slightly nodular, horizontal walls occasionally pitted, indentures not observed.

\section{DESCRIPTION}

The petrified wood sample has grey color; dimensions are $7 \times 8 \times$ $19 \mathrm{~cm}$ (Fig. 3). In cross section, growth ring boundaries are distinct, transition from earlywood to latewood is mostly gradual (Fig. 4A, B). Measured diameters of tracheids and pits are given in Table 1.

Axial resin canals with thin walled epithelial cells present mostly in latewood zone (Fig. 4A, B). Traumatic resin canals present (Fig. 4C). In tangential section, rays uniseriate (Fig. 4D), and fusiform rays present (Fig. 4E). Rays occasionally biseri- ate or partly biseriate (Fig. 5A). Big rays with idioblast-like cells present (Fig 5B-D). Ray cells uniform in some rays, and heterocellular, wider or narrower (Fig. 5D-E). Height of uniseriate rays up to 27 cells (Fig. 4C), height of fusiform rays up to 30 cells and wider (Fig. 4D and Fig. 5D). Average height of rays 4-15 cells. Radial resin canals with thin-walled epithelial cells. Axial parenchyma cells occasionally present, and generally smooth transverse end walls (Fig. 5F-G and I), and slightly nodular (Fig. 5H). Axial resin canal visible in radial section (Fig. 6A). Tracheid pitting in radial walls of earlywood 1-2 (-3) seriate opposite and crassulae formation common (Fig. 5B-D). Cross-field pitting pinoid in $1(-2)$ rows of usually 1-2(-6) pits per cross-field (Fig. 6E, F). End walls of ray parenchyma cells smooth, no indentures observed. Rays heterocellular. Ray tracheids present, 1-3 seriate, smooth walled (Fig. 6G). Ray cells smooth walled (Fig. 6E-H) and occasionally pitted. These descriptive features are also provided in Appendix A based on "Criteria used according the IAWA for fossil conifers" by Wheeler et al. (2004).

\section{DISCUSSION}

A typical haploxylon Pinuxylon has thin walled axial and radial resin canals, pinoid type of cross-field pitting, ray tracheids with smooth horizontal and end walls of ray parenchyma (Mantzouka et al. 2019). The wood samples investigated in the present study meet all the anatomical features of a Pinuxylon, but having in addition an "unusual" occurrence of seemingly idioblastic cells in rays. Idioblasts (oil and/or mucilage cells) represent a special feature in angiosperms and have been studied in several scientific works and even categorized (e.g., Mantzouka et al. 2016), but they are not a common characteristic in conifers.

Many fossil pine species described with smooth or weakly dentate horizontal walls of ray tracheids (see table 1 in Wang et al. 2017) were described. They comprise Pinus uniseriata and Pinus nanfengensis (Wang et al. 2017), Pinus albicauloides S.K. Choi \& K. Kim (Choi et al. 2010), Pinus cf. armandii Franchet (Yi et al. 2002), Pinus chemrylensis Blokhina (Blokhina 1995), Pinus hatamuraenase Jeong \& Kim (Jeong et al. 2012), Pinus henanensis J.J. Yang (Yang et al. 1990), Pinoxylon dakotense (Knowlton) Read (Nishida \& Nishida 1995), Pinuxylon arjuzanxianum Huard (van der Burgh (1973), Pinuxylon cembraeforme Rössler (Rössler 1937), Pinuxylon parryoides (Kräusel) van der Burgh (van der Burgh (1964, 1973), Pinuxylon pinastroides (Kraus) Stockmans \& Willière (van der Burgh (1973), Pinuxylon ponderosoides van der Burgh (van der Burgh (1973), Pinuxylon similkameenensis Miller (Miller 1973), Pinuxylon tarnocziense (Tuzśon) Greguss (van der Burgh (1973), Pinuxylon woolardii Tidwell, Parker \& Folkman (Tidwell et al. 1986), Pinuxylon zobelianum (Goeppert) Kräusel (van der Burgh 1964). Later, Mantzouka et al. (2019) demonstrated that extant pines are separated in two groups: Haploxylon pines, with smooth horizontal walls of ray tracheids, and Diploxylon pines, with dentate horizontal walls of ray tracheids. Because our Pinuxylon has smooth horizontal walls of ray tracheids, we classified it as 

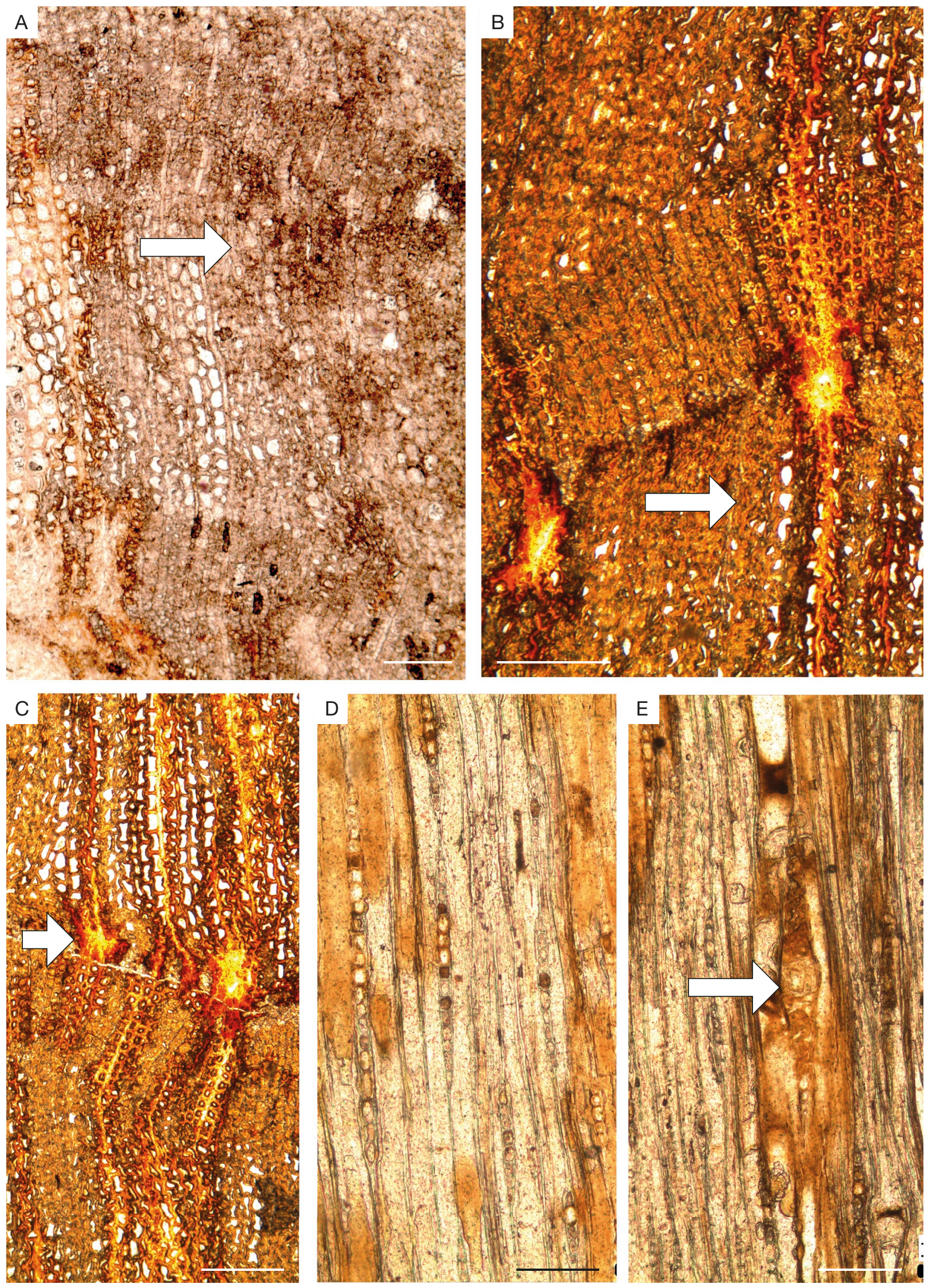

FIG. 4. - Wood features of Lesbosoxylon kemaliyensis Akkemik \& Mantzouka, sp. nov.: A, B, transversal section with gradual transition from earlywood to latewood (arrow); C, traumatic resin canals in transversal section (arrow); D, uniseriate rays in tangential section (arrow); E, fusiform ray with horizontal resin canal, and resinous cells around the ray (arrow). Scale bars: A-C, E, $200 \mu \mathrm{m} ; \mathrm{D}, 100 \mu \mathrm{m}$. 
a Haploxylon pine. Some Haploxylon fossil pine woods were also mentioned in Mantzouka et al. (2019). They are Pinuxylon haploxyloides Greguss, with a single pinoid cross field pit per cross-field (Sakala et al. 2018), Pinuxylon succiniferum (Göppert) Kräusel emend. Dolezych (Dolezych et al. 2011) without axial parenchyma, and Pinuxylon nightigalense Vozenin-Serra (Vozenin-Serra 1971) with taxodioid to ooporoid pittings in cross-fields.

Axial parenchyma present in the here studied fossil wood clearly sets them apart from numerous species, which have smooth or weakly dentate horizontal walls of ray tracheids given in Wang et al. (2017). The fossil Pinuxylon species with axial parenchyma are Pinus chemrylensis Blokhina (Blokhina 1995) and Pinus hatamuraenase Jeong \& Kim (Jeong et al. 2012). Furthermore, Süss \& Velitzelos (1993) described Pinoxylon parenchymatosum Süss \& Velitzelos with axial parenchyma. Another fossil pine wood, Pinuxylon sp. cf. Pinus sylvestris L. (Iamandei et al. 2011, $2016 \mathrm{~b}$ ) has also axial parenchyma and 2-3 seriate rays, and the same is true for Pinuxylon marinasii Iamandei \& Iamandei (Iamandei \& Iamandei 1999). Pinoxylon yabei Shimakura (Shimakura 1936) has also axial parenchyma in growth ring boundaries (Kim et al. 2005). Hence, to our knowledge, only six fossil pine species have axial parenchyma cells.

In Pinus chemrylensis, cross-field pitting is piceoid, taxodioid and cupressoid, and tracheidal pitting is uniseriate (Blokhina 1995). In our wood, cross-field pitting is pinoid, and tracheidal pitting is biseriate and, commonly, with crassulae.

In Pinus hatamuraenase, cross-field pitting is pinoid and taxodioid, and tracheidal pitting is biseriate (Jeong et al. 2012). Our wood is similar to this fossil species, but differs in having crassulae and idioblasts. Our specimen has also been compared with Pinuxylon sp. cf. Pinus sylvestris (Iamandei et al. 2011, 2016b) from the Romanian Carpathians which has axial parenchyma and 2-3-seriate rays. Pinoxylon yabei Shimakura is completely different from our fossil having axial parenchyma only in growth ring boundaries, bordered pits arranged in three rows, thick-walled epithelial cells of resin canals, occurrence of traumatic canals and 1-3 seriate rays with up to 70 cells height.

In Pinuxylon marinasii Iamandei \& Iamandei (Iamandei \& Iamandei 1999), the wood has features very close to our fossil pine sample. It has axial parenchyma, which may rarely be seen in longitudinal section. Ray heights up to 35 cells, horizontal walls of ray tracheids are smooth and slightly wavy, or with small denticles on inner walls. Tracheid pits $1(-2)$ seriate, crassulae rare, and 1-3(4) taxodioid small pits in cross-fields. In contrast, our wood has large pinoid type cross-field pits, 1-2 (very rarely up to 5) per cross-field, and ray tracheids are not denticulate in inner walls.

Comparing our specimen with the fossil pine woods from Greece many differences occur: Pinoxylon paradoxum Süss \& Velitzelos (Süss \& Velitzelos 1994b) from Lesbos Island is characterized by the presence of spiral thickenings and P. pseudoparadoxum Süss \& Velitzelos (Süss \& Velitzelos 1994b, Lesbos Island) has high rays of up to 50 cells.

Süss \& Velitzelos $(2009,2010)$ have introduced the genus Lesbosoxylon as a special wood type of Pinuxylon with idio- blastic cells in rays established from anatomical studies from "in situ" (L. paradoxum [Süss \& Velitzelos 1994b, 2010]) in the area of Bali Alonia Petrified Forest Park and from dispersed (not "in situ") small wood remnants ("lose Stücke" as stated in Süss \& Velitzelos 1994b and wood pebbles in rubble: "Kieselholzfunde", "lose Gerölle" as stated in Süss \& Velitzelos 2009, 2010) from Chamandroula (near Eressos) and Megalonissi (Nisiopi) islet (L. pseudoparadoxum [Süss \& Velitzelos 1994b, 2010]) and Eressos area (L. ventricosuradiatum, L. diversiradiatum, L. graciliradiatum [Süss \& Velitzelos 2010]). This genus is still regarded as a distinct genus represented only by the fossil "protopinaceous" woods from Lesbos Island (e.g., Velitzelos et al. 2014). The present study showed that this fossil "protopinaceous" wood is also found in Anatolia during the early Miocene.

Süss \& Velitzelos (2009) also mentioned this unusual feature in modern wood of Pinus pseudostrobus but we did not find mentioning about the occurrence of idioblasts in this modern species when doing a literature search. In the same paper (Süss \& Velitzelos 2009), resin ducts are mentioned reported in the work of Werker \& Fahn (1969).

Pinoxylon parenchymatosum Süss \& Velitzelos (Süss \& Velitzelos 1993) from Lemnos Island is characterized by the occurrence of axial parenchyma, a feature in accordance with our fossil. Our specimen is closely similar to two more species from Lesbos Island identified by Süss \& Velitzelos (2009): Lesbosoxylon (= Pinoxylon) diversiradiatum Süss \& Velitzelos because the latter has bi-seriate rays and L. (= Pinoxylon) graciliradiatum Süss \& Velitzelos which has large rays with "idioblast-like" cells. It might also be very similar to Lesbosoxylon (= Pinoxylon) ventricosuradiatum Süss \& Velitzelos (e.g. rays with "idioblast-like" cells and pits in the cross-field and ray tracheids not ascertainable) (Süss \& Velitzelos 2010).

Based on a number of diagnostic characteristics, coniferous wood with resin canals, distinct growth ring boundaries, axial and radial resin canals with thin-walled epithelial cells, $1-2(-3)$ seriate of bordered pits on radial walls of tracheids, heterocellular, uniseriate to partly biseriate rays, presence of axial parenchyma, smooth walls of ray tracheids and having big rays with idioblast-like cells, we consider our wood to represent a new fossil Lesbosoxylon species and named it Lesbosoxylon kemaliyensis Akkemik \& Mantzouka, sp. nov.

\section{BOTANICAL AFFINITIES}

According to the discussion in Tidwell et al. (1986), the family Pinaceae is represented by 10 genera in the extant flora (note that Tidwell did not consider Nothotsuga in his classification; for a modern classification of Pinaceae, see e.g., Neale \& Wheeler 2019). Neale \& Wheeler (2019) suggested 11 genera within the family Pinaceae including Nothotsuga, and recognized two subfamilies Pinoideae and Abietoideae. Furthermore, based on ray morphology and whether normal horizontal and vertical resin ducts are present in their wood, four groups have been distinguished (Greguss 1955; Watari 1956; Roy \& Hills 1972) as follows:

- Group 1: Pinaceous woods having heterogeneous rays with both horizontal and vertical resin ducts [Pinus L., 

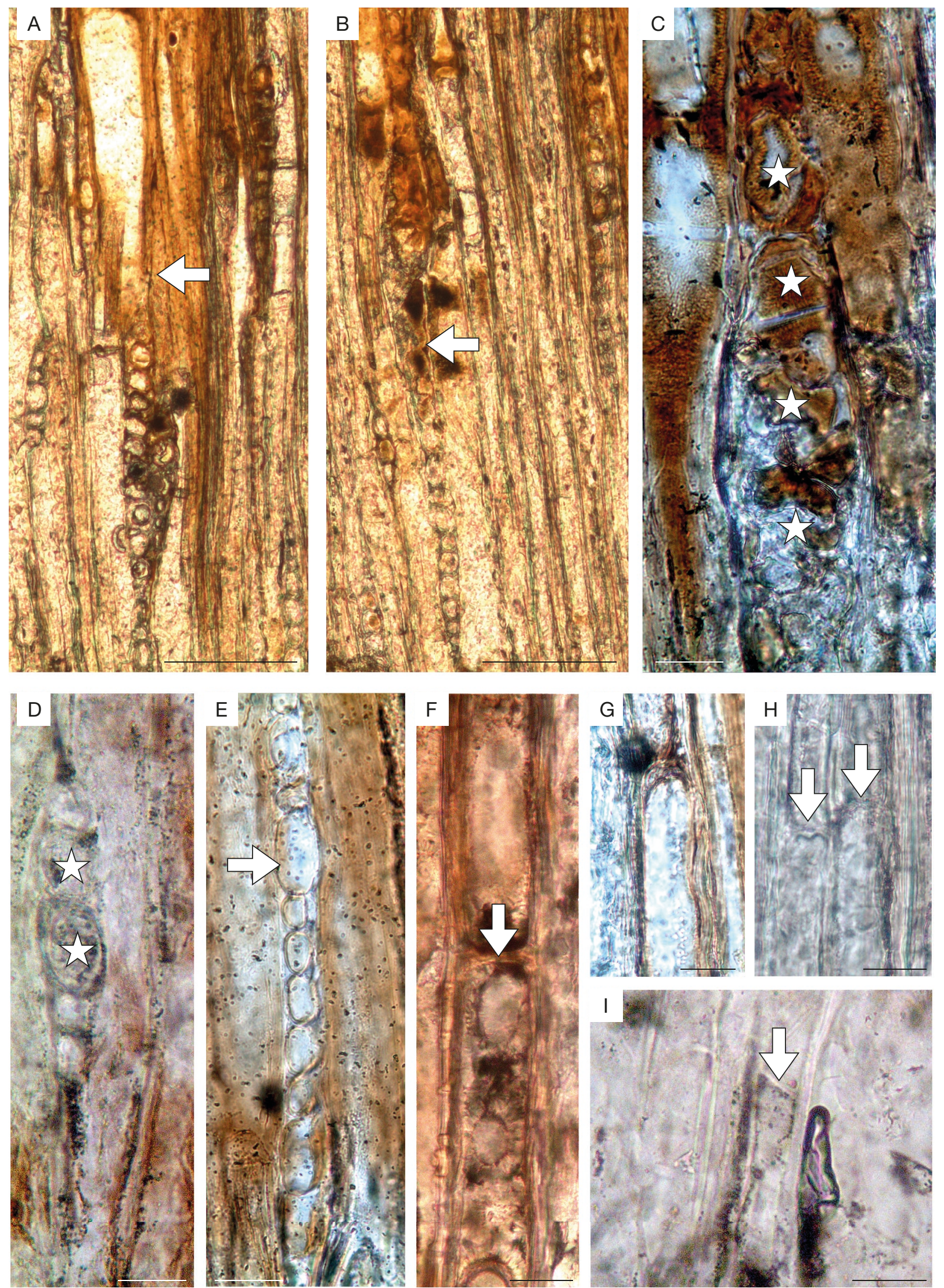

FIG. 5. - Wood features of Lesbosoxylon kemaliyensis Akkemik \& Mantzouka, sp. nov.: A, Biseriate ray (black arrow) and tracheids with resin material (white arrow); B, a tall fusiform ray (arrow): C, D, big rays with idioblast-like cells (asterisk): $\mathbf{E}$, heterocelluler ray cells in a ray; F, G, H, I, axial parenchyma cells with smooth end walls (white arrows), and slightly nodular end walls (black arrow). Scale bars: A, B, E, $100 \mu \mathrm{m} ; \mathrm{C}, \mathrm{D}, \mathrm{F}-\mathrm{I}, 20 \mu \mathrm{m}$. 
Picea A. Dietrich, Larix Miller, Cathaya Chun \& Kuang (Hu \& Wang 1984), and Pseudotsuga Carrière]. This group reflects a monophyletic group within Pinaceae (Neale \& Wheeler 2019). Our wood, which has heterogeneous rays with horizontal and vertical resin ducts, falls clearly into this group.

- Group 2: Pinaceous woods with heterogeneous rays, without normal resin ducts (Cedrus Trew. and Tsuga (Endlicher) Carrière). This may reflect the plesiomorphic state in Pinaceae, where Cedrus is sister to the rest of the family.

- Group 3: Pinaceous woods with homogeneous rays and only vertical resin ducts (Keteleeria Carrière).

- Group 4: Pinaceous woods having homogeneous rays and lacking any resin ducts (Pseudolarix (J. Nelson) Rehder and Abies Miller). The loss of resin ducts may have accurred independently in these two genera (cf. Neale \& Wheeler 2019).

Regarding the presence of wood parenchyma, in Patel (1971) based on Bailey (1909): in Pinus, as has been noted, Gothan asserts the absence of spirals, yet Penhallow (1907) has described them as occurring in Pinus taeda L. Bailey (1909) also observed this feature in Pinus attenuata Lemm (Patel 1971). Recently, DM (co-author of this paper) has also observed them in Pinus attenuata and several other species. Furthermore, spiral thickenings occur in the ray tacheids of Pinus balfouriana A. Murr., they are strongly developed in certain specimens and only feebly in others. Pinus strobiformis Engelm. and other pines from the southwestern United States show traces of their occurrence. The occurrence of spiral thickening in the wood of radiata pine described by Barker (1927) was in fact, the spiral checking which is associated with an abnormality called compression wood (Patel 1971).

However, Tidwell et al. (1986) stated, based on Greguss (1955) and Penhallow (1907), that wood parenchyma might occur very rarely in some Pinus species such as $P$. monophylla Torr. \& Frem. and P. massoniana Lamb., whereas spiral thickenings were described in Pinus taeda.

Güner et al. (2017) described 3-needle and 2-needle pine macrofossils from middle Miocene strata in southwestern Turkey. Three-needled samples were compared to Pinus canariensis C. Sm. (subgenus Pinus; diploxylon pines) and members of the North American section Trifoliae in the same subgenus. Two-needled pine samples were also closer to the subgenus Pinus. From early Miocene strata of Güvem, cones with affinities to subgenus Pinus and leaf fascicles with affinities to subgenera Pinus and Strobus (haploxylon pines) are known (Kasapligil 1977; Denk et al. 2017a). Fossil pine cones and seeds from Greece have been related to Pinus roxburghii Sarg. and P. canariensis C.Sm. (Mai \& Velitzelos 2007; Boyd 2009; Kvaček et al. 2014). In the palynological record, diploxylon and haploxylon pines have been distinguished for many early and middle Miocene sites in Turkey (Bouchal et al. 2016, 2017; Bouchal 2018; Denk et al. 2017a). These findings show that both haploxylon and diploxylon pines were present during the Miocene in Turkey. Due to the smooth ray tracheids, our wood can be considered to represent a haploxylon pine species.

Taking into account the work by Esteban et al. (2004) and mainly after using the presence of diffuse axial parenchyma and of axial and radial resin canals as the most important "filters", the following modern pines are closely similar to our fossil-species: Pinus canariensis C. Sm in Buch, P. douglasiana Martínez, P. hartwegii Lindl., P. lawsonii Roezl ex Gordon, $P$. montezumae Lamb., P. tabuliformis Carriére and P. thunbergii Parl. in Candolle. From the above mentioned species we excluded the following ones:

Pinus douglasiana Martínez is excluded because it does not have well-defined growth rings; $P$. hartwegii Lindl., and P. thunbergii Parl. in Candolle are excluded because they do not have thin-walled epithelial cell resin canals; $P$. lawsonii Roezl ex Gordon is excluded because it has spiral thickenings in all the axial tracheids (a feature not in accordance with our wood); P. tabuliformis Carriére is excluded because it does not have pinoid cross-field pits.

Among the remaining species, Pinus canariensis C. Sm in Buch and P. montezumae Lamb., taking into account also the "whole plant concept" sensu Sakala (2004) and Kvaček (2008), we suggest that our fossil is more closely related to Pinus canariensis C. Sm \& Buch. However, some features of this species such as: 1) spiral thickenings present but not in all the axial tracheids; 2 ) bordered pits present on the tangential walls of the axial tracheids; and 3) dentate ray tracheids with the height of the dentations $<2.5 \mu \mathrm{m}$, are not seen in our sample. Ray parenchyma with nodular axial walls and ray parenchyma with resin canal are features shared by Pinus canariensis and Lesbosoxylon kemaliyensis Akkemik \& Mantzouka, sp. nov. Based on cone and leaf imprints, Kasapligil (1977) also described P. canariensis from the early Miocene of central Anatolia.

\section{CONCLUSION}

In this study, we describe a new pine species (Lesbosoxylon kemaliyensis Akkemik \& Mantzouka, sp. nov.) from the Miocene of Turkey and compare it to fossil and living pine species. Among living species, the fossil-species resembles most closely the endemic $P$. canariensis (subgenus Pinus, diploxylon pines) from the outer Canary Islands. A large number of macrofossils (leaf fascicles and cones) and microfossils (dispersed pollen) demonstrate that both diploxylon and haploxylon pines were common in Turkey during the early and middle Miocene. Today, Turkey has only five diploxylon pine species (Pinus brutia Ten., P. halepensis Mill., P. nigra Arnold, P. pinea L., and P. sylvestris L.), and all haploxylon pine species are extinct. The here described fossil-species suggests that the lineage leading to the modern P. canariensis had a much greater distribution during large parts of the Cenozoic.

\section{Acknowledgements}

We thank Şevket Gültekin for his contribution to provide the sample. We also thank the reviewers (Dr Thomas Denk and Dr Stanila Iamandei) for their valuable suggestions. Funding has been provided to the second author (DM) by the Alexander von Humboldt Foundation. 

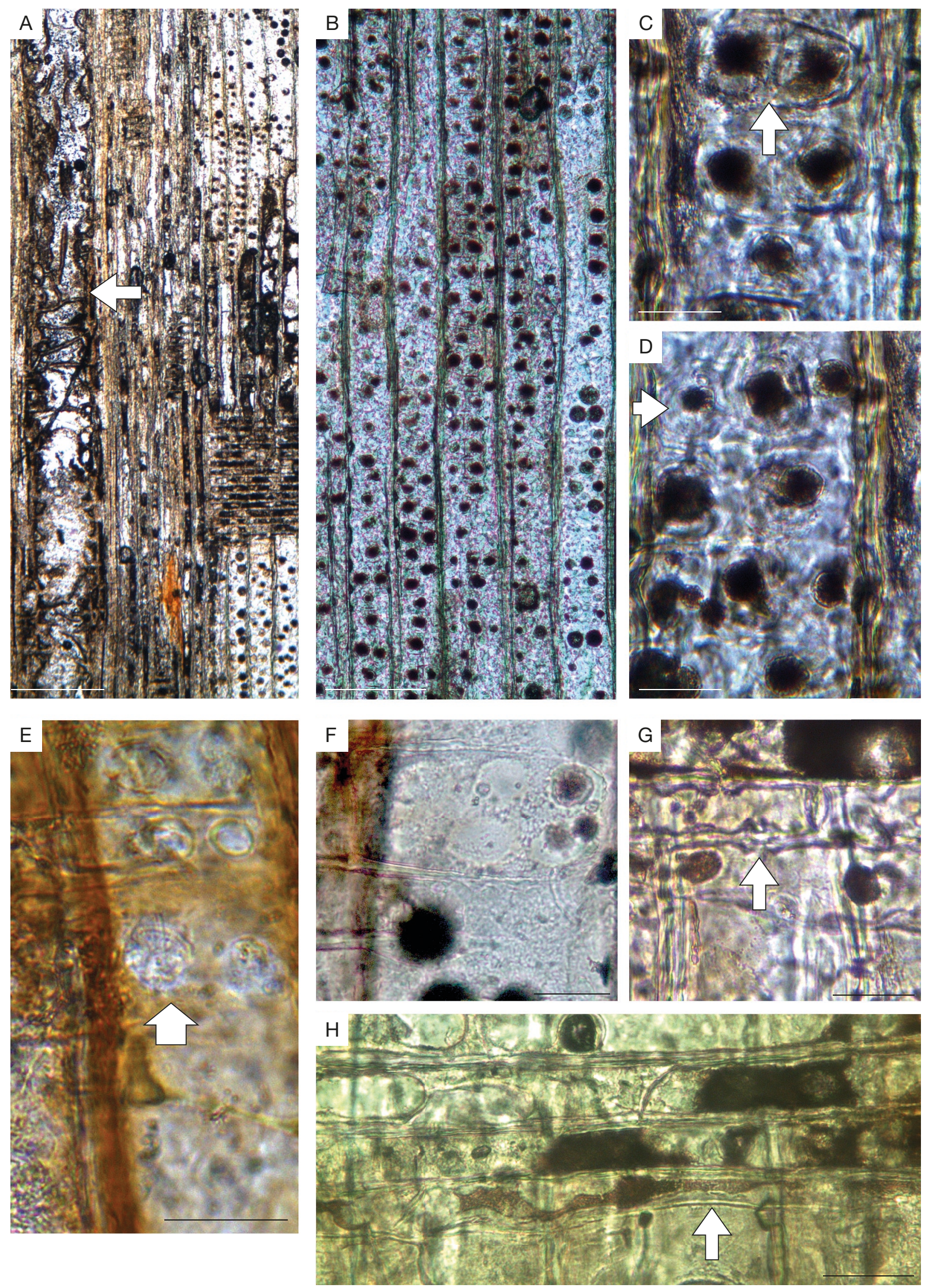

FiG. 6. - Wood features of Lesbosoxylon kemaliyensis Akkemik \& Mantzouka, sp. nov.: A, radial section with axial resin canal (arrow); B-D, 1-3 seriate of tracheidal pitting, and crassulae formation common (white arrow); $\mathbf{E}$, pinoid type cross-field pitting, 1-2 pits per cross-field on one row, and smooth end wall of ray cell; $\mathbf{F}$, six pits on two rows in a cross-field (arrow); G, pit border on ray tracheids (arrow); H, one-two seriate of smooth-walled ray tracheids (arrow). Scale bars: A, $200 \mu \mathrm{m}$; B, $100 \mu \mathrm{m} ; \mathrm{C}-\mathrm{G}, 20 \mu \mathrm{m} ; \mathrm{H}, 30 \mu \mathrm{m}$. 


\section{REFERENCES}

Aккемік Ü. 2019. - New fossil wood descriptions from Pliocene of central Anatolia and presence of Taxodioxylon in Turkey from Oligocene to Pliocene. Turkish Journal of Earth Science 28: 398-409. https://doi.org/10.3906/yer-1805-24

AKKEMIK Ü. \& SAKINÇ M. 2013. - Sequoioxylon petrified woods from the Mid to Late Oligocene of Thrace (Turkey). IAWA Journal 34 (2): 177-182. https://doi.org/10.1163/2294193200000015

AKKemik Ü., KÖSE N. \& PoOle I. 2005. — Sequoioiodae (Cupressaceae) woods from the upper Oligocene of European Turkey (Thrace). Phytologia Balcanica 11 (2): 119-131.

AKkemik Ü., TÜrkoĞlu N., Poole I., ÇıçeK I., Köse N. \& GÜrgen G. 2009. - Woods of a Miocene Petrified Forest near Ankara, Turkey. Turkish Journal of Agriculture and Forestry 33: 89-97. http://doi.org/10.3906/tar-0807-17

AKKeMiK Ü., ARslan M., PoOle I., Tosun S., KÖSE N., Karlioğlu Kilıç, N. \& Aydin A. 2016. — Silicified woods from two previously undescribed early Miocene forest sites near Seben, northwest Turkey. Review of Palaeobotany and Palynology 235: 31-50. https://doi.org/10.1016/j.revpalbo.2016.09.012

AKKEMIK Ü., ACARCA N. N. \& HatipoĞLU M. 2017. - The first Glyptostroboxylon from the Miocene of Turkey. IAWA Journal 38 (4): 561-570. https://doi.org/10.1163/22941932-20170181

Akkemik Ü., Atici G., Poole I. \& Çobankaya M. 2018. Three new silicified woods from a newly discovered earliest Miocene forest site in the Haymana Basin (Ankara, Turkey). Review of Palaeobotany and Palynology. 254: 49-64. https:// doi.org/10.1016/j.revpalbo.2018.04.012

AKKEMIK Ü., AKKILIÇ H. \& GÜNGÖR Y. 2019. — Fossil wood from the Neogene of the Kilyos coastal area in Istanbul, Turkey. Palaeontographica Abteilung B Palaeobotany, Palaeophytology 299 (4-6): 133-185. https://doi.org/10.1127/palb/2019/0065

Akkiraz M. S., Akgün F., Utescher T., Bruch A. A. \& MosBRUGGER V. 2011. - Precipitation gradients during the Miocene in Western and Central Turkey as quantified from pollen data. Palaeogeography, Palaeoclimatology, Palaeoecology 304: 276-290. https://doi.org/10.1016/j.palaeo.2010.05.002

Aktimur H. T., Atalay Z., Tekirli M. E. \& Yurdakul M. E. 1988. - Munzurdağı ile Çavuşdağ Arasının Jeolojisi. Mineral Research and Exploration Institute of Turkey Report 8320: 30 (in Turkish, unpublished).

Aktimur H. T., Tekerli M. E. \& Yurdakul M. D. 1990. Sivas-Erzincan tersiyer havzasinin jeolojisi. Bulletin of the Mineral Research and Exploration 111: 25-36.

Atici G., Dönmez M., Çobankaya M., Sevin M., GÜndoĞdu E., EsIRTGEN E. \& ŞıMŞEK E. 2014. - 1:100.000 scale Geological Map of Ankara J29. General Directorate of Mineral Research and Exploration (MTA), Ankara (unpublished).

BAILEY I. W. 1909. - The structure of the wood in the Pineae. Botanical Gazette 48 (1): 47-55. https://doi.org/10.1086/329935

BARKER C. S. 1927. - A Structure Study of the Secondary Wood of Pinus radiata. School of Forestry, Canterbury University, Christchurch, New Zealand (unpublished).

Bayam N. N. A., Akkemik Ü., Poole I. \& Akarsu F. 2018. Further Contributions to the early Miocene forest vegetation of the Galatian Volcanic Province, Turkey. Palaeobotanica Electronica, 21.3.40A: 1-42. https://doi.org/10.26879/816

BILGIÇ T. 2008. - 1:100 000 scale Turkish Geological Map series. Divriği-J40 Quadrangle (explanatory notes in Turkish). General Directorate of Mineral Research and Exploration Institute (MTA), Ankara.

Blokhina N. I. \& Bondarenko O. V. 2016. - Fossil Wood of Pinus priamurensis sp. nov. (Pinaceae) from the Miocene Deposits of the Erkovetskii Brown Coal Field, Amur Region. Paleontological Journal 50 (3): 311-318. https://doi.org/10.1134/ S0031030116030023
Blokhina N. I. 1995. - Petrified wood of pine Pinuxylon chemrylensis sp. nov., from the Paleogene of Kamchatka. Paleontological Journal 29 (2A): 141-147.

BOUCHAL J. M. 2018. - The middle Miocene palynofloras of the Salihpaşalar lignite mine (Yatağan Basin, southwest Anatolia): environmental characterisation and comparison with palynofloras from adjacent basins. Palaeobiodiversity and Palaeoenvironments 99: 591-636. https://doi.org/10.1007/s12549-018-0345-0

Bouchal J. M., Grímsson F., ZetTer R. \& DenK T. 2016. - The middle Miocene palynoflora and palaeoenvironments of Eskihisar (Yatağan Basin, southwestern Anatolia): a combined LM and SEM investigation. Botanical Journal of the Linnean Society. 182: 14-79. https://doi.org/10.1111/boj.12446

Bouchal J. M., Mayda S., ZetTer R., GrimsSOn F., AKGÜn F. \& DENK T. 2017. - Miocene palynofloras of the Tinaz lignite mine, Muğla, southwest Anatolia: Taxonomy, palaeoecology and local vegetation change. Review of Palaeobotany and Palynology 243: 1-36. https://doi.org/10.1016/j.revpalbo.2017.02.010

BoyD A. 2009. - Relict conifers from the mid-Pleistocene of Rhodes, Greece. Historical Biology 21: 1-15. https://doi. org/10.1080/08912960903033301

Cater J. M. L., Hanna S.S, Ries A. C. \& Turner P. 1991. - Tertiary evolution of the Sivas basin, Central Turkey. Tectonophysics 195: 29-46. https://doi.org/10.1016/0040-1951(91)90142-F

Choi S. K., Kim K., Jeong E. K., Terada K., Suzuki M. \& Uematsu H. 2010. - Fossil woods from the Miocene in the Yamagata Prefectur, Japan. IAWA Journal31 (1): 95-117. https:// doi.org/10.1163/22941932-90000009

Denk T., GÜNer T. H., KvaČEK Z. \& Bouchal M. J. 2017a. The early Miocene flora of Güvem (Central Anatolia, Turkey): a window into early Neogene vegetation and environments in the Eastern Mediterranean. Acta Palaeobotanica (Monograph) 57: 237-338. https://doi.org/10.1515/acpa-2017-0011

Denk T., Velitzelos D., GÜner T., Bouchal J. M., GrimsSON F. \& GRIMM G. W. 2017b. - Taxonomy and palaeoecology of two widespread western Eurasian Neogene sclerophyllous oak species: Quercus drymeja Unger and Q. mediterranea Unger. Review of Palaeobotany and Palynology 241: 98-128. https://doi. org/10.1016/j.revpalbo.2017.01.005

DenK T., Grimm G. W., Manos P. S., Deng M. \& Hipp A. 2017c. An updated infrageneric classification of the oaks: review of previous taxonomic schemes and synthesis of evolutionary patterns, in Gil-Peregrin E., Peguero-Pina J. J., Sancho-KnapiK D. (eds), Oaks Physiological Ecology. Exploring the Functional Diversity of Genus Quercus. Springer, Cham: 13-38 (Tree Physiology; 7). https://doi.org/10.1007/978-3-319-69099-5_2

Dewey J. F., Hempton M. R., Kidd W. S. F., Saroglu F. \& ŞENGÖR A. M. C. 1986. - Shortening of continental lithosphere: the neotectonics of Eastern Anatolia-a young collision zone, in COWARD M. P. \& Ries A. C. (eds), Collision Tectonics. Geological Society, London, Special Publications 19 (1): 3-36. https://doi.org/10.1144/GSL.SP.1986.019.01.01

DOLEZYCH M. \& SCHNEIDER W. 2006. - Inkohlte Hölzer und Cuticulae dispersae aus dem 2. Miozänen Flözhorizont im Tagebau Welzow (Lausitz) - Taxonomie und vergleichende feinstratigraphisch-fazielle Zuordnung. Zeitschrift für Geologische Wissenschaften 34: 165-259.

DolezyCh M., FIsCher T. \& GrÖSChKe A. 2011. — Pinuxylon succiniferum (Goeppert) Kraeusel emend. Dolezych - amberized wood from Goeppert's type material restudied. Mauritiana (Altenburg) 22: 43-60.

ERdoĞAN B., AKay E. \& UĞUR S. M. 1996. - Geology of the Yozgat region and evolution of the collisional Çankırı basin. International Geology Review 38: 788-806. https://doi. org/10.1080/00206819709465362

esteban L. G., De Palacios P., Casasus A. G. \& Fernandez G. 2004. - Characterization of the xylem of 352 conifers. Investigación Agraria: Sistemas y Recursos Forestales 13: 452-478 
GÖKTEN E. 1993. - Geology of the southern boundary of Sivas Basin in eastern Ulas (Sivas, central Anatolia): Tectonic development related to the closure of Inner Tauride ocean. Bulletin of the Turkish Association of Petroleum Geologists 5: 35-55 (in Turkish).

GÖrÜr N., OkTAy F. Y., Seymen I. \& ŞENGÖr A. M. C. 1984. - Paleotectonic evolution of the Tuzgölü basin complex; Sedimentary record of a Neotethyan closure, in DiXON J. E. \& ROBERTSON A. H. F. (eds), The geological evolution of the Eastern Mediterranean. Geological Society of London, Special Publications 17: 467-482. https://doi.org/10.1144/GSL.SP.1984.017.01.34

Greguss P. 1955. - Xylotomische Bestimmung der Heute Lebenden Gymnospermen. Academia Kiado, Budapest, 308 p.

GÜNer H. T., BOUChal J. M., KÖSE N., GÖKTAŞ F., MaYda S. \& DENK T. 2017. — Landscape heterogeneity in the Yatağan Basin (southwestern Turkey) during the middle Miocene inferred from plant macrofossils. Palaeontolographica Abteilung B 296 (1-6): 113-171.

GÜNGÖR Y., AKKEMIK Ü., KASAPÇI C. \& BAŞARAN E. 2019. Geology and woods of a new fossil forest from the early Miocene of Gökçeada (Turkey). Forestist 69 (1): 22-34. https://doi. org $/ 10.26650 /$ forestist.2019.412545

GÜRER Ö. F. 1996. - Geological position and genesis of Hasançelebi Alkaline Magmatism at the Eastern Taurides (NW Malatya). Turkish Journal of Earth Sciences 5: 71-89.

GÜrer Ö. \& Aldanmaz E. 2002. - Origin of the Upper Cretaceous-Tertiary sedimentary basins within the Tauride-Anatolide platform in Turkey. Geological Magazine 139: 191-197. https:// doi.org/10.1017/S0016756802006295

HU Y. S. \& WANG F. H. 1984. - Anatomical studies of Cathaya (Pinaceae). American Journal of Botany 71: 727-735. https:// doi.org/10.1002/j.1537-2197.1984.tb14180.x

IAMANDEI S. \& IAMANDEI E. 1999. - Fossil conifer wood from Prăvăleni-Ociu, Metalliferous Mts. Acta Palaeontologica Romaniae 2: 201-212.

IAMANDEI E., IAMANDEI S. \& Diaconu F. 2011. — Fossil woods in the collection of Drobeta-Turnu Severin Museum. Acta Palaeontologica Romaniae 7: 199-218.

IAMANDEI S., IAMANDEI E., BOZUKOV V. \& TSENOV B. 2016a. New Oligocene fossil woods from Rhodopes, Bulgaria. Acta Palaeontologica Romaniae 12 (2): 47-65.

IAMANDEI S., IAMANDEI, E. \& MiclĂUȘ C. 2016b. - A petrified wood from the lower Miocene of Valea Mare (Faraoani, Bacau). Acta Palaeontologica Romaniae 12 (2): 21-27.

Iamandei S., IAmandei, E. \& AKkemik Ü. 2018. - Neogene Palmoxylon of Turkey. Acta Palaeontologica Romaniae 14 (1): 31-45.

INSIDEWOOD 2004. - InsideWood Database. Published on Internet: http://insidewood.lib.ncsu.edu/search [last access on $5^{\text {th }}$ October 2018].

Jeong E. K., Kim K. Suzuki M. \& Uemura K. 2012. — Daijimatype conifer wood assemblage of the Hatamura Formation (Middle Miocene) in the Akita Prefecture, Japan. Geosciences Journal 16 (2): 115-125. https://doi.org/10.1007/s12303-012-0018-3

Karlioğlu N., AKKeMiK Ü. \& CANer H. 2009. - Detection of some woody plants in Late Oligocene forests of Istanbul. Turkish Journal of Agriculture and Forestry 33: 577-584. https://10.3906/ tar-0811-25

KASAPLIGIL B. 1977. - A late Tertiary conifer-hardwood forest from the vicinity of Güvem village, near Kızılcahaman, Ankara. Bulletin of the Mineral Research and Exploration 88: 94-102 (in Turkish).

KavaK K. S., Poisson A. \& Guezou J. C. 1997. — Tectonostratigraphy of the southern Sivas Tertiary Basin (Central Turkey) and comparison with landsat MSS imagery. International Geology Review 39: 353-364. https://doi.org/10.1080/00206819709465277

Kayacik H., AytuĞ B., Yaltirik F., Sanli I., Efe A., AKkemik Ü. \& INAN M. 1995. - Sequoiadendron giganteum (Lindl) Buchh. trees living near Istanbul in Late Tertiary. Journal of the Faculty of Forestry Istanbul University 45: 15-22.
Kayseri ÖZer M. S., Sancay R. H., Şen Ş., SÖZeri K., Métais G., AyYILDIZ T. \& VAROL B. E. 2017. - Paleoenvironment of the Late Oligocene from the Kağızman-Tuzluca Basin (northeastern Anatolia) based on the micro- and macrofloras. Turkish Journal of Earth Science 26 (3): 227-248.

Kelling G., GÖKÇEN S. L., GÖKÇEN N. S., GÖKTEN E. \& BROMLEY A. J. 1989. - Tectono-Sedimentary Evolution of a Neo-Tethyan Collisional Trough: Sivas-Refahiye Basin Central Turkey. 28th International Geological Congress, Washington, DC. Abstracts 2 (3): 171, 172

KIM K., SuZUKI M. \& OH C. 2005. - Re-examination of Prof. Shimakura's coniferous fossil wood microscope slides deposited in Tohoku University Museum. Bulletin of the Tohoku University Museum 4: 17-72. http://hdl.handle.net/10097/54396

KVAČEK Z. 2008. - Whole-plant reconstructions in fossil angiosperm research. International Journal of Plant Sciences 169 (7): 918-927. https://doi.org/10.1086/589694

KvačeK Z., TeOdoridis V., MaZOUCH P. \& RoIron P. 2014. Fossil seed cones of Pinus L. (sect. Pinus, subsect. Pinaster Loudon, Sula group) from the late Neogene and early Pleistocene of Europe. Palaeontographica Abteilung B 291 (1-6): 131-164.

Mai D. H. \& Velitzelos E. 2007. — The fossil flora of Kallithea (Rhodos, Greece) at the Pliocene/Pleistocene boundary. Palaeontographica Abteilung B 277: 75-99.

MANTZOUKA D. 2018. - The first report of Cryptocaryoxylon from the Neogene (early Miocene) of Eurasia (Eastern Mediterranean: Lesbos and Lemnos Islands, Greece). Fossil Imprint 74 (1-2): 29-36. https://doi.org/10.2478/if-2018-0002

Mantzouka D., KvaČeK Z., TeOdoridis V., Utescher T., Tsaparas N. \& Karakitsios V. 2015. - A new late Miocene (Tortonian) flora from Gavdos Island in southernmost Greece evaluated in the context of vegetation and climate in the Eastern Mediterranean. Neues Jahrbuch für Geologie und Paläontologie - Abhandlungen 275 (1): 47-81. https://doi.org/10.1127/ njgpa/2015/0448

Mantzouka D., Karakitsios V., SaKala J. \& Wheeler E. 2016. - Using idioblasts to group Laurinoxylon species - Case study from the Oligo-Miocene of Europe. IAWA Journal 37 (3): 459-488. https://doi.org/10.1163/22941932-20160147

Mantzouka D., SaKala J., KvaČeK Z., Koskeridou E. \& IoAKim C. 2019. - Two fossil conifer species from the Neogene of Alonissos Island (Iliodroma, Greece). Geodiversitas 41 (3): 125-142. https://doi.org/10.5252/geodiversitas2019v41a3. http://geodiversitas.com $/ 41 / 3$

Mathiesen F. J. 1970. - Palaeobotanical investigations into some cormophytic macrofossils from the Neogene Tertiary lignites of central Jutland. Part II. Gymnosperms. Munksgaard, København, 69 p.

MiLlER C. N. 1973. - Silicified cones and vegetative remains of Pinus from the Eocene of British Columbia. Contributions from the Museum of Paleontology, The University of Michigan 24 (10): 101-118. http://hdl.handle.net/2027.42/48477

Neale D. B. \& Wheeler N. 2019. - The Conifers, in Neale D. B. \& WheEler N. (eds), The Conifers: Genomes, Variation and Evolution. Springer, Cham: 1-21. https://doi.org/10.1007/978-3319-46807-5 1

Nishida M. \& Nishida H. 1995. — Pinoid woods with resin canals from the upper Cretaceous of Hokkaido and Saghalien. Journal of Plant Research 108: 161-170. https://doi.org/10.1007/ BF02344340

ÖZGÜVEN-ERTAN K. 1971. - Sur un bois fossile de Taxodiaceae dans la flore Néogène d'Istanbul (Turquie d'Europe): Sequoioxylon egemeni n. sp. Revue de la Faculté des Sciences de l'Université d'Istanbul, Série B, 36: 89-114.

ÖZgÜVEn-ERTAN K. 1977. — La structure d'une Cupressaceae fossile appartenant au Miocène trouvée dans la région d'Éjpn. J. Histor. Botée en Turquie: Cupressinoxylon akdiki n. sp. Revue de la Faculté des sciences de l'Université d'Istanbul, Série B, 42 (1-2): 1-15. 
Patel R. N. 1971. - Anatomy od stem and root wood of Pinus radiata D. Don. New Zealand Journal of Forestry Science 1: 37-49.

Penhallow D. P. 1907. - A report on fossil plants from the international boundary survey for 1903-1905. Transactions of the Royal Society of Canada, III, 1 (4): 287-351.

Philippe M. \& BAmford M. K. 2008. - A key to morphogenera used for Mesozoic conifer-like woods. Review of Palaeobotany and Palynology 148: 184-207. https://doi.org/10.1016/j.revpalbo.2007.09.004

Poisson A., Guezou J. C., Temiz H., Gürsöy H., Inan S., ÖZTÜrK A., KavaK K \& ÖZden S. 1995. - The Sivas Basin in its tectonic setting [abs.]: General evolution. Second International Turkish Geology Workshop, Sivas, Turkey. Abstract volume: 88.

Poisson A., Guezou J. C., Öztürk A., Inan S., Temiz H., GÜrsoy H., KavaK K. S. \& ÖZden S. 1996. — Tectonic setting and evolution of the Sivas basin, Central Anatolia, Turkey. International Geology Review 38: 833-853. https://doi. org/10.1080/00206819709465366

RÖSSLER W. 1937. — Pliozäne Koniferenhölzer aus der Um-gebung von Gleichenberg in Steiermark. Mitteilungen des Naturwissenschaftlichen Vereines für Steiermark 74: 64-97.

RoY S. K. \& Hills L. V. 1972. — Fossil woods from the Beaufort Formation (Tertiary), northwestern Banks Island, Canada. Canadian Journal of Botany 50: 2637-2654. https://doi.org/10.1139/b72-337

SAKALA J. 2004. - The 'Whole-Plant' Concept in Palaeobotany with Examples from the Tertiary of Northwestern Bohe-Mia, Czech Republic with Particular Reference to Fossil Wood. PhD thesis. MS, Institute of Geology and Palaeontology, Charles University, Prague, Czech Republic and Laboratoire de Paléobotanique et Paléoécologie, Université Pierre et Marie Curie, Paris, 94 p.

SAKAla J., SelmeCZI I. \& Hably L. 2018. - Reappraisal of Greguss' fossil wood types and figured specimens from the Cenozoic of Hungary: Overview, corrected geology and systematic notes. Fossil Imprints 74 (1-2): 101-114. https://doi.org/10.2478/if-2018-0008

SANCAY R. H., BATI Z., IȘIK U., KirICI S. \& AKÇA N. 2006. Palynomorph, foraminifera, and calcareous nannoplankton biostratigraphy of Oligo-Miocene sediments in the Muş Basin, Eastern Anatolia, Turkey. Turkish Journal of Earth Science 15 (3): 259-319.

SAYADI S. 1973. - Contribution à l'étude de la flore miocène de la Turquie. Thèse de $3^{\mathrm{e}}$ cycle en paléontologie (paléobotanique), Paris IV, $81 \mathrm{p}$.

Selmeier A. 1990. - Dichrostachyoxlon zirkelii (Felix), Mimosoideae, a silicified wood from Miocene sediments of Küçük Çekmece Lake (Turkey). Mitteilungen der Bayerischen Staatssammlung für Paläontologie und Historische Geologie 30: 121-135.

Selmeier A. 2001. - Silicified Miocene woods from the North Bohemian Basin (Czech Republic) and from Kuzuluk, district Adapazari (Turkey). Mitteilungen der Bayerischen Staatssammlung für Paläontologie und Historische Geologie 41:111-144

SHIMAKURA M. 1936. - On the fossil wood of Torreya nucifera Sieb. et Zucc. from the Pleistocene of Kanagawaken, Japan. The Journal of the Geology Society of Japan 43 (512): 297-302. https:// doi.org/10.5575/geosoc.43.297

ŞENGÖR A. M. C. \& KIDD W. S. F. 1979. — Post-collisional tectonics of the Turkish-Iranian plateau and a comparision with Tibet. Tectonophysics 55 (3-4): 361-376. https://doi.org/10.1016/00401951(79)90184-7

ŞENGÖR A. M. C. \& Yilmaz Y. 1981. - Tethyan evolution of Turkey: A plate tectonic approach. Tectonophysics 75: 181-241.

Süss H. 1997. - Tetraclinoxylon velitzelosi sp. nova, ein neues fossiles Holz aus tertiären Schichten des Versteinerten Waldes von Lesbos. Feddes Repertorum 108: 289-298. https://doi.org/10.1002/ fedr. 19971080502

SÜss H. \& VelitZELos E. 1994a. — Ein neues fossiles Koniferenholz, Taxoceoxylon biseriatum sp. nov., aus tertiaren Schichten der Insel Lesvos, Griechenland. Feddes Repertorium 105 (5-6): 257-269. https://doi.org/10.1002/fedr.19941050502
Süss H. \& Velitzelos E. 1994b. — Zwei neue tertia re Holzer der Gattung Pinoxylon Knowlton emend. Read aus dem Versteinerten Wald von Lesvos, Griechenland. Feddes Repertorium 105 (7-8): 403-423. https://doi.org/10.1002/fedr.19941050702

Süss H. \& Velitzelos E. 1997. — Fossile Hölzer der Familie Taxodiaceae aus tertiären Schichten des Versteinerten Waldes von Lesbos, Griechenland. Feddes Repertorum 108: 1-30. https://doi. org/10.1002/fedr.19971080102

SüsS H. \& Velitzelos E. 1998. - Thujoxylon antissurn sp. nov. ein fossiles Wurzelholz aus tertiären Schichten des Versteinerten Waldes von Lesbos, Griechenland. Feddes Repertorum 109: 341 350. https://doi.org/10.1002/fedr.19981090502

Süss H. \& Velitzelos E. 1999. - Chimairoidoxylon gen. nov. ein endemisches Holzfossil aus dem Tertiar von Lesbos, Griechenland. Feddes Repertorum 110:329-339. https://doi.org/10.1002/ fedr.19991100502

Süss H. \& Velitzelos E. 2000. — Zwei neue fossile Hölzer der Formgattung Podocarpoxylon Gothan aus TertiärenSthichten der Insel Lesbos, Griechenland. Feddes Repertorum 111 (3-4): 135149. https://doi.org/10.1002/fedr.20011120301

SÜss H. \& VelitZelos E. 2001. - Chimairoidoxylon conspicuum sp. nova, ein neues fossiles Holz der Formgattung Chimairoidoxylon Süss \& Velitzelos emend. Mit einer Übersicht über das Vorkommen fossiler Hölzer auf der Insel Lesbos, Griechenland. Feddes Repertorum 112: 149-157. https://doi.org/10.1002/fedr.20011120301

Süss H. 2003. - Zwei neue fossile Hölzer der Morphogattung Ginkgoxylon Saporta emend. Süss aus tertiären Schichten der Insel Lesbos, Griechenland, mit einer Übersicht über Fossilien mit ginkgoaler Holzstruktur. Feddes Repertorum 114 (5-6): 301319. https://doi.org/10.1002/fedr.200311001

Süss H. \& Velitzelos E. 1993. - Eine neue Protopinaceae der Formgattung Pinoxylon Knowlton emend. Read, P.parenchymatosum sp. nov., aus tertiären Schichten der Insel Limnos, Griechenland Mit einer Tafel. Feddes Repertorum 104 (5-6): 335-341. https:// doi.org/10.1002/fedr.19931040508

Süss H. \& VelitZelos E. 2009. - Zwei neue fossile Hölzer der Morphogattung Pinoxylon Knowlton emend. Read aus dem Tertiär der Insel Lesbos, Griechenland. Feddes Repertorium 120 (1-2): 3-14. https://doi.org/10.1002/fedr.200811191

Süss H. \& Velitzelos E. 2010. - Lesbosoxylon gen. nov., eine neue Morphogattung mit dem Typus Lesbosoxylon ventricosuradiatum sp. nova aus dem Tertiar der Insel Lesbos, Griechenland. Feddes Repertorum 121 (1-2): 18-26. https://doi.org/10.1002/ fedr.201011124

TEKIN E. 2001. - Stratigraphy, Geochemistry and Depositional Environment of celestite-bearing gypsiferous formations, in Tertiary Ulaş-Sivas Basin, Turkey. Turkish Journal of Earth Science 10: 35-49.

Tidwell W. D., Parker L. R. \& Folkman V. K. 1986. — Pinuxylon woolardii sp. nov., a new petrified taxon of Pinaeae from the Miocene basalts of Eastern Oregon. American Journal of Botany 73 (11): 1517-1524. https://doi.org/10.1002/j.1537-2197.1986. tb10901.x

VAN DER BURGH J. 1964. - Hölzer der niederrheinischen Braunkohlenformation. I. Hölzer der Braunkohlengrube "Anna" zu Haanrade (Niederländisch Limburg). Acta Botanica Neerlandica 13 (2): 250-301. https://doi.org/10.1111/j.1438-8677.1964. tb00156.x

VAN DER BURGH J. 1973. — Hölzer der niederrheinischen Braunkohlenformation, 2. Holzer der Braukohlengruben "Maria Theresia" zu Herzogenrath, "Zukunft West" zu eschweiler und "Victor" (Aulpich Mitte) zu Zulpich, nebst einer systematisch-anatomischen bearbeitung der gattung Pinus L. Review of Palaeobotany and Palynolology 15: 73-275. https://doi.org/10.1016/0034-6667(73)90001-8

Velitzelos D., Bouchal J. M., Denk T. 2014. - Review of the Cenozoic floras and vegetation of Greece. Review of Palaeobotany and Palynology 204: 56-117. https://doi.org/10.1016/j. revpalbo.2014.02.006 
Vozenin-SERra C. 1971. - Notes sur des bois mésozoïques et cénozoïques du Viêtnam et du Cambodge. Archives géologiques Viêtnam 14: 1-39.

Wang H. B., Oskolski A. A., Jaceues F. M. B., Wang Y.-H. \& ZHOU Z.-K. 2017. — Lignified woods of Pinus (Pinaceae) from the late Miocene of central Yunnan, China, and their biogeographic and paleoclimatic implications. Palaeoworld 26: 553-565. https:// doi.org/10.1016/j.palwor.2016.06.003

WATARI S. 1956. - Some abietinean woods from the Tertiary of Japan. Journal of the Faculty of Science, University of Tokyo, Section III, Botany 4: 419-437.

Werker E. \& FAHN A. 1969. - Resin ducts of Pinus halepensis Mill. Their structure, development and pattern of arrangement. Botanical Journal of the Linnean Society 62 (4):379-411. https:// doi.org/10.1111/j.1095-8339.1969.tb01974.x

Wheeler E. A., BAAs P. \& Gasson P. E. (EDS) 2004. — IAWA list of microscopic features for softwood identification. IAWA Journal 25: 1-70. https://doi.org/10.1163/22941932-90000349

YANG J. J., QI G. F. \& XU R. H. 1990. — Studies on fossil woods excavated from the Dabie Mountains. Scientia Silvae Sinicae 28 (4): 379-383 (in Chinese, with English abstract).

YAVUZ-IșIK N. 2007. — Pollen analysis of coal-bearing Miocene sedimentary rocks from the Seyitömer Basin (Kütahya), Western Anatolia. Geobios 40: 701-708. https://doi.org/10.1016/j. geobios.2006.11.006

Yilmaz H., ARIKAL T. \& Yilmaz A. 2001. — Geology of the Günes ophiolite (Divriği-Sivas). Proceedings of the $54^{\text {th }}$ Geological Congress of Turkey, Ankara: 54-65.

Yi T. M., Li C. S., Jiang X. M. \& Wang Y. 2002. — Pliocene Rhododendron and Pinus fossil woods of Yunnan Province and paleoclimate. Journal of Palaeogeography 4 (4): 90-98 (in Chinese with English abstract).

$40 \quad$ Growth ring boundaries distinct;

43 Transition from earlywood to latewood mostly gradual;

45 Tracheid pitting in radial walls of earlywood 1-2 (-3) seriate;

46 Arrangement of tracheid pitting opposite;

54 Latewood tracheids generally thin-walled;

56 Torus presents;

72 Axial parenchyma occasionally presents;

73 Diffuse;

76 Transversal end walls of axial parenchyma smooth;

78 Slightly nodular;

79 Ray tracheids present, 1-3 seriate;

85 Ray cells smooth walled;

86 End walls of ray parenchyma cells smooth;

87 Ray cells smooth walled and occasionally pitted;

91 Cross-field pitting pinoid;

98 Predominantly 1-2 (rarely up to 6) pits per cross-field on 1(-2) rows;

103 Average height of rays generally 4-15 cells (rarely up to 30 cells);

107 Rays uniseritate, and fusiform rays present;

108 Rays occasionally biseriate or partly biseriate;

109 Axial resin canals presents;

111 Traumatic resin canals presents;

117 Epithelial cells with thin walled.

Idioblast-like cells present in rays. 